\title{
Occupational Trajectories and Immigrant Worker Health
}

\author{
Allison Crollard, MS, MN, RN, \\ Research Coordinator, Department of Environmental and Occupational Health Sciences, \\ University of Washington School of Public Health
}

\author{
A. B. de Castro, PhD, MSN/MPH, RN, and \\ Associate Professor and Director, Occupational and Environmental Health Nursing Program, \\ University of Washington School of Nursing \\ Jenny Hsin-Chun Tsai, PhD, ARNP, PMHCNS-BC \\ Associate Professor, University of Washington School of Nursing, Seattle, WA
}

\section{Abstract}

During their initial years in the receiving country, many immigrants experience occupational downgrading. Downgrading is a loss of occupational status between one's last job in the home country and first job in the receiving country, often resulting in overeducation or overqualification. Although the extent and determinants of such occupational trajectories have been characterized, the connection to immigrant worker health has not been widely examined. However, an emerging body of knowledge indicates that negative health outcomes are associated with overeducation and overqualification in general worker populations, suggesting similar experiences by immigrant workers. This article provides an overview of the magnitude and conceptualization of occupational downgrading, overeducation, and overqualification and discusses implications for immigrant worker health. Occupational health professionals should spearhead research efforts on occupational downgrading, raise public awareness about the issue, and serve as advocates for immigrant workers' rights.

\begin{abstract}
Worldwide, nearly 200 million individuals migrate annually across national borders, an increase of $144 \%$ in the past 40 years. More than $60 \%$ of these migrants move from developing to developed countries seeking better employment and economic opportunities. More than half of all migrants are estimated to be either employed or actively seeking employment (Global Conference of International Migration, 2005).

During their initial years in the receiving country, many immigrants experience occupational downgrading or downward occupational mobility (Akresh, 2006, 2008; Chiswick, 1978; Chiswick, Lee, \& Miller, 2005; Chiswick \& Miller, 2009; Friedberg, 2000). This occurs when there is a loss of occupational status or prestige between one's last job in the country of origin and first job in the receiving country. Often, immigrants are undervalued, having limited job opportunities that match their actual skills and educational level. Thus, immigrants who encounter downward occupational mobility frequently hold jobs for which they are overeducated or overqualified (Akresh, 2006; Chiswick, 1978; Chiswick et al., 2005; Chiswick \& Miller, 2009; Friedberg, 2000).
\end{abstract}

\footnotetext{
Address correspondence to Allison Crollard, MS, MN, RN, Research Coordinator, Department of Environmental and Occupational Health Sciences, University of Washington School of Public Health, 4225 Roosevelt Way NE, Suite 100, Seattle, WA 98195. crollard@uw.edu.

The authors disclose that they have no significant financial interests in any product or class of products discussed directly or indirectly in this activity, including research support.
} 
Prior research on occupational downgrading, over-education, and overqualification in immigrant worker populations has primarily focused on measuring magnitude and characterizing causes. The health consequences of these phenomena for immigrant workers have largely been unexplored. Some evidence indicates that overeducation and overqualification are associated with adverse health effects, including poor self-rated health, depression, anxiety, and ischemic heart disease, among the general working population (Friedland \& Price, 2003; Johnson \& Johnson, 1996, 1997, 1999; Lundberg, Kristenson, \& Starrin, 2009; Peter, Gassler, \& Geyer, 2007; Smith \& Frank, 2005).

This article examines the issue of occupational trajectory specifically among immigrant workers by reviewing the literature on occupational downgrading, overeducation, and overqualification and discussing implications for immigrant worker health. The extent of occupational downgrading, overeducation, and overqualification among immigrant workers and related theories and conceptualizations are summarized; considerations related to the health and well-being of immigrants are discussed; and areas for further research and challenges facing occupational health professionals are illuminated.

\section{UNDERSTANDING OCCUPATIONAL TRAJECTORIES EXPERIENCED BY IMMIGRANT WORKERS}

Both longitudinal and cross-sectional studies have shown that occupational downgrading is widespread in countries receiving high numbers of immigrants. Akresh (2006) estimated that approximately half of immigrants to the United States were downgraded unrelated to country of origin. In Sweden, Rooth and Eckberg (2006) found that approximately 45\% of all immigrants experienced downgrading in their first job on arrival. Studies in Israel showed that downward occupational mobility among male immigrants ranged from $32 \%$ during a period of few immigrant arrivals to $64 \%$ during a period of mass migration due to the collapse of the Soviet Union, and that, on arrival, immigrants earned $25 \%$ less than natives (Friedberg, 2000; Raijman \& Semyonov, 1998). Chiswick et al. (2005) reported downgrading in occupational prestige among immigrants in Australia by comparing last job held in the country of origin with first job after arrival. Occupational downgrading can also occur among native-born workers (e.g., a decrease in occupational status subsequent to being laid off or taking a leave from the labor market), although little is known of its prevalence (Jacobs, 1999; Lene, 2011).

The occurrence of overeducation among immigrants has also been researched in common immigrant-receiving countries. In Australia, $15 \%$ to $27 \%$ of English-speaking immigrants were found to be overeducated for their jobs, and 32\% to $49 \%$ of non-native English speakers were overeducated compared to $7 \%$ to $22 \%$ of Australian natives (Green, Kler, \& Leeves, 2007). In the United Kingdom, $27 \%$ of immigrant men, compared to $23 \%$ of nativeborn workers, had higher levels of education than required by their jobs (Lindley, 2009). Using 2000 U.S. Census data, Chiswick and Miller (2009) found that, overall, U.S.-born men experienced slightly more overeducation (32\%) than foreign-born men (27\%) for their jobs. In addition, they found that immigrants who had lived in the United States less than 10 years were more likely to be overeducated than those in the United States for 10 to 30 years. Similarly, among immigrants in Canada, Wald and Fang (2008) found that overeducation varied with duration. Recent immigrants (less than 10 years in Canada) had overeducation rates up to $48 \%$, whereas non-recent immigrants had a rate (35\%) closer to that of natives $(31 \%)$. Although overqualification is often coupled with overeducation and occupational downgrading, limited information about prevalence is available specifically for immigrant worker populations. 
Additional research has focused on understanding why occupational downgrading, overeducation, and overqualification occur among immigrants, including how various factors influence their labor market experiences. Early research investigated earning patterns of immigrant groups. For instance, Chiswick (1978) found that newly arrived immigrant men earned less than U.S.-born men with similar levels of education, work experience, and demographic characteristics; immigrants who had been in the United States for 10 to 15 years or more had earnings equaling or exceeding those of natives. An explanation offered for this was immigrants' inability to apply their experiences, skills, and education gained in their home country to the job market of the receiving country, often referred to as an imperfect transferability or portability of human capital and skills (Akresh, 2006, 2008; Chiswick, Lee, \& Miller, 2003; Chiswick \& Miller, 2009; Duleep \& Regets, 1999; Friedberg, 2000). For example, immigrants' language abilities, skills, or labor market experiences may not be relevant in the receiving country, thus leading to initial downgrading, overeducation, or overqualification (Chiswick, 1978; Chiswick \& Miller, 2009). However, with increased duration in the receiving country, immigrants might obtain skills, experiences, and education, increasing opportunities for upward mobility in the labor market (Chiswick, 1978). The imperfect transferability of human capital may not always lead to extreme changes in occupational status (e.g., trained white collar professionals compelled to work as blue collar laborers) and may minimally account for the overrepresentation of immigrant workers in high-hazard industries (Akresh, 2006; Chiswick et al., 2005).

Chiswick (1978) also posited that self-selection among immigrants could also lead to upward mobility following initial downgrading. For those migrating for economic reasons, opportunities for labor market success outweighed the costs of migration (i.e., migration was more likely to occur among those who were highly able and motivated). From this perspective, although such immigrants experience downward mobility on arrival, their abilities and motivation may aid in subsequent upgrading.

Chiswick's original ideas were supported by subsequent longitudinal studies, which also explored longerterm effects of factors that contribute to occupational mobility for immigrants (Akresh, 2006, 2008; Chiswick et al., 2005; Duleep \& Regets, 1997). Chiswick and Miller (2009) found that overeducation was more common among immigrants with 17 or more years of formal education than those with less. Similarly, other studies reported that downward occupational mobility was more often experienced by immigrants with the highest levels of skills and work experience (Akresh, 2006; Chiswick \& Miller, 2009). Among immigrants in Israel who were educated in their home countries, the positive effect of education on earnings was smaller compared to those educated in-country (Friedberg, 2000). Chiswick and Miller (2008) reported that among immigrants in the United States, those educated in less-developed regions received lower payoffs for their education than those educated in developed regions. Also, immigrants with country-specific skills or certifications were found to encounter imperfect human capital transfer (Akresh, 2008; Chiswick et al., 2005). For instance, workers in occupations requiring in-depth knowledge of government or legal systems (e.g., lawyers or civil servants) had difficulty finding similar jobs in the receiving country. Certification or licensure requirements in fields such as teaching and nursing limited some immigrants' employment opportunities.

Class of admission (i.e., category of immigration as defined by immigration law [U.S. Department of Homeland Security, 2010]) has been another important factor in describing immigrants' occupational mobility. In the United States, common classes of admission have included employment-based immigrants searching for employment or improved financial opportunities; family-based immigrants who are sponsored by relatives; refugees who relocate due to persecution in the home country; and diversity immigrants who are granted 
entrance based on a lottery system (Akresh, 2008). Employment-based immigrants are admitted based on job skills and typically have employment arranged for immigration. Studies have shown that this group experienced minimal occupational downgrading, with some even experiencing upgrading on arrival to the receiving country (Akresh, 2006, 2008). Refugees, on the other hand, typically with limited ability to prepare for migration, tended to encounter more severe occupational downgrading than immigrants who were able to plan transition to a new country (Akresh, 2006, 2008; Chiswick et al., 2005). However, refugees experienced more rapid upward occupational mobility than other classes of immigrants because they were more likely to invest in improving their human capital due to uncertainty regarding return to their country of origin (Akresh, 2008). Family-based immigrants and diversity immigrants also often experienced downward mobility on arrival to the receiving country because they did not necessarily have the desired human capital or employment arrangements of employment-based immigrants (Akresh, 2008).

\section{RELEVANCE FOR HEALTH}

Although a significant body of knowledge about occupational trajectories and determinants of occupational mobility for immigrants has been developed, effects on health and wellbeing have not been thoroughly examined. Only one study was identified by the authors as directly addressing the issue. In a qualitative study of immigrants in Ontario, Canada, Dean and Wilson (2009) interviewed 22 highly skilled immigrants who arrived through a skilled worker program. Study participants, although highly skilled, were either unemployed and not currently working at all or underemployed (i.e., working part-time in an occupation outside one's field of expertise) and had been in Canada for less than 2.5 years. All reported experiencing stress, anxiety, depression, irritation, and frustration secondary to unemployment or underemployment. They cited difficulties in finding stable employment in their field of expertise as leading to lack of income, loss of job skills, and loss of social status, which contributed to mental health issues. Approximately half also described physical health problems such as hypertension induced by stress or musculoskeletal disorders from the unfamiliar strenuous working conditions in jobs outside their field. Findings did not reflect other classes of admission, immigrant workers with fewer skills, or immigrants who had been living in Canada for longer periods.

Despite the paucity of information on the relationship between occupational trajectory and health status among immigrants, studies have examined the association between overeducation and overqualification and health outcomes in general worker populations. Some have shown that overqualified and overeducated workers were more likely to experience poor or declining self-rated health compared to workers appropriately matched to their jobs (Friedland \& Price, 2003; Johnson \& Johnson, 1996, 1997, 1999; Smith \& Frank, 2005). Overqualified and overeducated workers also had higher rates of adverse mental health outcomes, including depression, anxiety, and psychological distress (Friedland \& Price, 2003; Gal, Kaplan, Gross, \& Levav, 2008; Johnson \& Johnson, 1996, 1997, 1999; Lundeberg et al., 2009; O’Brien \& Feather, 1990). Some evidence also suggests more negative physical health outcomes among overeducated workers, including higher risk of ischemic heart disease (Peter et al., 2007) and low-birth weight deliveries (Meyer, Warren, \& Reisine, 2010), than among workers with expected levels of education for their jobs. In many of these studies, researchers noted that stress is often associated with overeducation and overqualification. A mismatch between occupational attainment and education or experience is theorized to lead to psychosocial stress through conflicting social expectations and feelings of injustice or deprivation (House \& Harkins, 1975; Jackson, 1962; Wegener, 1991). Psychosocial stress can then lead to a variety of mental and physical health disorders, such as depression, anxiety, cardiac diseases, and poor general health and well-being (Adler et al., 2007). 
As occupational downgrading often coincides with overeducation or overqualification, it is likely also associated with similar negative health outcomes via similar pathways.

\section{DISCUSSION FOR IMMIGRANT WORKER HEALTH}

The health of individuals is closely tied to the work they do (Adler et al., 2007; Lipscomb, Loomis, McDonald, Argue, \& Wing, 2006). Work influences income, is often a source of health insurance, contributes to the psychosocial experiences of individuals, and exposes individuals to a variety of health and safety hazards, all of which are significant determinants of workers' physical and mental health. For these reasons, Lipscomb et al. (2006) assert that work be conceptualized as a determinant of health much like other social determinants of health, defined as "the conditions in which people are born, grow, live, work and age, including the health system ... shaped by the distribution of money, power and resources at global, national and local levels, which are themselves influenced by policy choices" (World Health Organization, 2012). In the growing body of knowledge about the role of social determinants, it has been argued that work may be a significant contributor to health disparities globally (Lipscomb et al., 2006). Thus, substantial changes in work for an individual, such as occupational downgrading, should be recognized when concerned with health.

Although immigrants are not the only individuals who may experience occupational downgrading, overeducation, or overqualification, they comprise a marginalized and underserved worker population and therefore are at particular risk for bearing a greater burden of adverse effects. For instance, immigrant workers are often overrepresented in high-hazard jobs and experience disproportionately high rates of occupational illnesses and injuries (McCauley, 2005; Schenker, 2010). In addition, occupational downgrading among immigrants may lead to higher levels of psychosocial stress via unmet expectations and frustrations resulting from fewer occupational opportunities associated with the undervaluing of human capital acquired abroad.

Further research is needed to fill the gap in understanding how occupational downgrading, overeducation, and overqualification contribute to poor health outcomes among immigrant worker populations. A principal issue to be investigated is whether the various types of occupational trajectories have differential effects on mental and physical health, and through what mechanisms. Prospective analyses might result in a truer examination of this relationship. Furthermore, data capturing health, employment, and occupational status factors prior to migration and into the post-migration period would minimize recall bias and aid in understanding such factors within country-and cultural-specific contexts. Studies might also benefit from incorporating methods used in the field of economics for classifying and ranking jobs and occupational status of immigrant workers. This information could then be linked to validated health status measures to test for possible associations.

\section{CHALLENGES FOR OCCUPATIONAL HEALTH PROFESSIONALS}

International migration is responsible for $75 \%$ of the population growth in the United States, making immigrants a fast growing work force in the country (Global Conference of International Migration, 2005). Given the diversifying population, it is essential that occupational health nurses and professionals recognize both the occurrence and potential health-related consequences of occupational downgrading, overeducation, and overqualification, explaining in large part the health disparities observed among immigrant populations. Accordingly, occupational health professionals must be aware of this issue to best address the health and safety needs of this growing presence of immigrants in the American labor force. 
To increase awareness and understanding of the adverse effects of occupational mobility among immigrants, research in this area could benefit from a variety of approaches and skills, including interdisciplinary collaboration, community-based participatory research (CBPR) design, cultural competency skills, and advocacy. With an interdisciplinary team of researchers and experts representing a variety of fields, a more complete understanding of the complexity of factors contributing to this occupational health issue could be achieved (Garrett, 2005). In the existing literature on occupational downgrading, overeducation, and overqualification, the field of economics offers theoretical conceptualizations and methodological approaches for measuring occupational mobility among immigrant populations. Additionally, the fields of psychology and sociology provide further understanding about the meaning of overeducation and overqualification at the individual and population health levels. Future studies on occupational trajectories and health could be enhanced by integrating such perspectives with core public health disciplines such as community health, occupational health, and epidemiology, which bring expertise on assessing health-related outcomes.

Furthermore, involving actual immigrant workers in developing research studies using a CBPR approach would strengthen study designs and facilitate worker empowerment (Israel, Schulz, Parker, \& Becker, 1998). As described by Israel et al. (1998), CBPR engages "local knowledge and local theory based on the lived experience of the people involved" (p. 180), which improves the overall quality and validity of research findings as well as the relevance and use of the findings by all involved. Elements of CBPR may be particularly useful in understanding the effects of occupational downgrading, overeducation, and overqualification at individual work sites, with the work force being a community in itself that can be engaged via focus groups, informal interviews, and involvement with company work practices and policy decisions.

Another element vital to understanding occupational trajectories and their relevance to health for immigrant workers is cultural competence, which the U.S. Department of Health and Human Services Office of Minority Health (2005) has defined as "a set of congruent behaviors, attitudes, and policies that come together in a system, agency, or among professionals that enables effective work in cross-cultural situations." Developing cultural competency, through workshops or training, may assist occupational health professionals to communicate with and serve their constituents (Williamson, 2007). Occupational downgrading, overeducation, and overqualification are complex matters, with significant variation in experiences among immigrants depending on factors such as language ability, country of origin, education, and race or ethnicity. Therefore, it is especially important to maximize cultural competence to better attend to individual circumstances and challenges of immigrant workers with the ultimate goal of improving occupational health. Finally, occupational health professionals must be advocates for immigrant workers and their distinct occupational health challenges such as occupational downgrading, overeducation, and overqualification. By raising public awareness of immigrant workers' issues, improving cultural sensitivity, spearheading immigrant worker research efforts, and lobbying for regulations and policies aimed at improving social and working conditions for immigrants, occupational health professionals can promote the health and well-being of this underserved population.

\section{CONCLUSION}

Occupational downgrading, overeducation, and overqualification add another dimension to the challenges faced by immigrant workers. For many immigrants, moving to a new country presents the likely possibility of losing occupational status, which has implications for health. Although the link between occupational trajectory and health status for immigrant 
workers needs further study, it is an issue that occupational health professionals must consider to provide quality services and care that improve the lives of this growing population of workers.

\section{REFERENCES}

Adler, A.; Stewart, J.; Cohen, S.; Cullen, M.; Roux, AD.; Dow, W., et al. Reaching for a healthier life: Facts on socioeconomic status and health in the U.S. 2007. Retrieved from www.macses.ucsf.edu

Akresh IR. Occupational mobility among legal immigrants to the United States. International Migration Review. 2006; 40(4):854-884.

Akresh IR. Occupational trajectories of legal U.S. immigrants: Downgrading and recovery. Population \& Development Review. 2008; 34(3):435-456.

Chiswick BR. The effect of Americanization on the earnings of foreign-born men. Journal of Political Economy. 1978; 86(5):897-921.

Chiswick BR, Lee YL, Miller PW. Patterns of immigrant occupational attainment in a longitudinal survey. International Migration. 2003; 41(4):47-69.

Chiswick BR, Lee YL, Miller PW. A longitudinal analysis of immigrant occupational mobility: A test of the immigrant assimilation hypothesis. International Migration Review. 2005; 39(2):332-353.

Chiswick BR, Miller PW. Why is the payoff to schooling smaller for immigrants? Labour Economics. 2008; 15:1317-1340.

Chiswick BR, Miller PW. The international transferability of immigrants' human capital. Economics of Education Review. 2009; 28:162-169.

Dean JA, Wilson K. 'Education? It is irrelevant to my job now. It makes me very depressed ...': Exploring the health impacts of under/unemployment among highly skilled recent immigrants in Canada. Ethnicity \& Health. 2009; 14(2):185-204. [PubMed: 18949654]

Duleep HO, Regets MC. Measuring immigrant wage growth using matched CPS files. Demography. 1997; 34(2):239-249. [PubMed: 9169280]

Duleep HO, Regets MC. Immigrants and human-capital investment. American Economic Review. 1999; 89(2):186-191.

Friedberg RM. You can't take it with you? Immigrant assimilation and the portability of human capital. Journal of Labor Economics. 2000; 18(2):221-251.

Friedland DS, Price RH. Underemployment: Consequences for the health and well-being of workers. American Journal of Community Psychology. 2003; 32(1/2):33-45. [PubMed: 14570433]

Gal G, Kaplan G, Gross R, Levav I. Status inconsistency and common mental disorders in the Israelbased work mental health survey. Social Psychiatry and Psychiatric Epidemiology. 2008; 43:9991003. [PubMed: 18587675]

Garrett LH. Interdisciplinary practice, education and research: The expanding role of the occupational health nurse. AAOHN Journal. 2005; 53(4):159-165. [PubMed: 15853291]

Global Conference of International Migration; Migration in an interconnected world: New directions for action; 2005. Retrieved from www.gcim.org/en

Green C, Kler P, Leeves G. Immigrant overeducation: Evidence from recent arrivals to Australia. Economics of Education Review. 2007; 26:420-432.

House JS, Harkins EB. Why and when is status inconsistency stressful? American Journal of Sociology. 1975; 81(2):395-412.

Israel BA, Schulz AJ, Parker EA, Becker AB. Review of community-based research: Assessing partnership approaches to improve public health. Annual Review of Public Health. 1998; 19:173202.

Jackson EF. Status consistency and symptoms of stress. American Sociological Review. 1962; 27(4): 469-480.

Jacobs S. Trends in women's career patterns and in gender occupational mobility in Britain. Gender, Work and Organization. 1999; 6(1):32-46.

Johnson GJ, Johnson WR. Perceived overqualification and psychological well-being. Journal of Social Psychology. 1996; 136(4):435-445. [PubMed: 8855378]

Workplace Health Saf. Author manuscript; available in PMC 2013 May 15. 
Johnson GJ, Johnson WR. Perceived overqualification, emotional support, and health. Journal of Applied Social Psychology. 1997; 27(21):1906-1918.

Johnson GJ, Johnson WR. Perceived overqualification and health: A longitudinal analysis. Journal of Social Psychology. 1999; 139(1):14-28. [PubMed: 10074866]

Lene A. Occupational downgrading and bumping down: The combined effect of education and experience. Labour Economics. 2011; 18(2):257-269.

Lindley J. The over-education of UK immigrants and minority ethnic groups: Evidence from the Labour Force Survey. Economics of Education Review. 2009; 28:80-89.

Lipscomb HJ, Loomis D, McDonald MA, Argue RA, Wing S. A conceptual model of work and health disparities in the United States. International Journal of Health Services. 2006; 36(1):25-50. [PubMed: 16524164]

Lundberg J, Kristenson M, Starrin B. Status incongruence revisited: Associations with shame and mental well-being. Sociology of Health \& Illness. 2009; 31(4):478-493. [PubMed: 19144081]

McCauley LA. Immigrant workers in the United States: Recent trends, vulnerable populations, and challenges for occupational health. AAOHN Journal. 2005; 53(7):313-319. [PubMed: 16097105]

Meyer JD, Warren N, Reisine S. Racial and ethnic disparities in low birth weight delivery associated with maternal occupational characteristics. American Journal of Industrial Medicine. 2010; 53(2): 153-162. [PubMed: 19444807]

O'Brien GE, Feather NT. The relative effects of unemployment and quality of employment on the affect, work values and personal control of adolescents. Journal of Occupational Psychology. 1990; 63:151-165.

Peter R, Gassler H, Geyer S. Socioeconomic status, status inconsistency and risk of ischaemic heart disease: A prospective study among members of a statutory health insurance company. Journal of Epidemiology \& Community Health. 2007; 61:605-612. [PubMed: 17568052]

Raijman R, Semyonov M. Best of times, worst of times, and occupational mobility: The case of Soviet immigrants in Israel. International Migration. 1998; 36(3):291-312. [PubMed: 12294000]

Rooth D, Eckberg J. Occupational mobility for immigrants in Sweden. International Migration. 2006; 44(2):57-77.

Schenker MB. A global perspective of migration and occupational health. American Journal of Industrial Medicine. 2010; 53:329-337. [PubMed: 20196095]

Smith P, Frank J. When aspirations and achievements don't meet: A longitudinal examination of the differential effect of education and occupational attainment on declines in self-rated health among Canadian labour force participants. International Journal of Epidemiology. 2005; 34:827-834. [PubMed: 15802380]

U.S. Department of Health and Human Services Office of Minority Health. What is cultural competency?. 2005. Retrieved from http://minorityhealth.hhs.gov/templates/browse.aspx? lvl=2\&lvlid=11

U.S. Department of Homeland Security. U.S. Citizenship and Immigration Services. 2010. Retrieved from www.uscis.gov/portal/site/uscis

Wald S, Fang T. Overeducated immigrants in the Canadian labour market: Evidence from the workplace and employee survey. Canadian Public Policy. 2008; 34(4):457-479.

Wegener B. Relative deprivation and social mobility: Structural constrains on distributive justice judgments. European Sociological Review. 1991; 7(1):3-18.

Williamson G. Providing leadership in a culturally diverse workplace. AAOHN Journal. 2007; 55(8): 329-335. [PubMed: 17847627]

World Health Organization. Social determinants of health. 2012. Retrieved from www.who.int/topics/ social_determinants/en

Workplace Health Saf. Author manuscript; available in PMC 2013 May 15. 


\section{IN SUMMARY}

1. Many immigrants experience occupational downgrading, overeducation, or overqualification on arrival to the receiving country, often due to difficulties transferring skills and human capital.

2. Among general worker populations, negative health consequences have been associated with overeducation and overqualification. It is unclear whether this is seen among immigrant worker populations, or in the case of occupational downgrading.

3. Occupational health professionals must be aware of potential effects of occupational downgrading, overeducation, or overqualification to better serve the growing immigrant work force and lead efforts in research and advocacy for these issues. 